J. Product. \& Dev., 22(2): 287- 306 (2017)

\title{
EFFECT OF SOME ORGANIC N FERTILIZERS ENRICHED WITH SPIRULINA PLATENSIS ALGAE AS A PARTIAL REPLACEMENT OF INORGANIC N FERTILIZER ON GRWOTH AND FRUITING OF SUPERIOR GRAPEVINES
}

\author{
Asmaa A. Ebrahim* and M. R. Gad El-Kareem** \\ *Viticulture Res. Dept. Hort. Res. Instit. ARC, Giza, Egypt. \\ ** Hort. Dept., Fac. of Agric., Souhag Univ., Egypt.
}

ABSTRACT

During 2014, 2015 and 2016 seasons, Superior grapevines were fertilized with three organic manures (poultry manure, plant compost and farmyard manure) enriched with Spirulina platensis algae as a partial replacement of 25 to $75 \%$ inorganic $N$. The merit was detecting the best source of organic $N$ enriched with Spirulina platensis algae applied with inorganic $N$ that responsible for producing higher yield with better quality berries.

Replacing $50 \%$ of inorganic $N$ by $50 \%$ organic manures enriched with Spirulina platensis algae at $20 \mathrm{ml} / \mathrm{vine}$ enhanced growth, yield and cluster weight while replacing $75 \%$ of inorganic $N$ by $75 \%$ organic manures enriched with Spirulina platensis algae at 40 $\mathrm{ml} / \mathrm{vine}$ gave favourable effects on vine nutritional status and quality of the grapes. Shot berries percentage was greatly declined by $N$ as $25 \%$ inorganic $N$ plus $75 \%$ organic manures enriched with Spirulina platensis algae at $40 \mathrm{ml} /$ vine. The best organic manures in this respect was poultry manure, plant compost and farmyard manure, in descending order.

Conclusively, for enhancing growth and yield of Superior grapevines, it is suggested to supply the vines with $N(60 \mathrm{~g} /$ vine/year) through $50 \%$ inorganic $N+50 \%$ poultry manure enriched with Spirulina platensis algae at $20 \mathrm{ml} /$ vine/year. Fertilizing the vines with $N$ as $25 \%$ inorganic $N+75 \%$ poultry manure enriched with $40 \mathrm{ml}$ Spirulina platensis algae gave the best results with regard to berries quality.

Keywords: Organic N, Inorganic N, Spirulina platensis algae, Superior grapevines. 


\section{INTRODUCTION}

Adjusting inorganic $\mathrm{N}$ fertilizer by organic manures enriched with Spirulina platensis algae is necessary for controlling, shot berries, and enhancing growth, yield and quality of the berries in grapevine cv. Superior.

Spirulina platensis algae contains polysaturated fatty acids, plant pigments, proteins, amino acids, vitamin A, vitamin B, lipids, carbohydrates and sugars (Koru, 2009 and Henrikson, 2010). Organic manures are responsible for enhancing organic matter, $\mathrm{N}$ fixation, availability of nutrients, secretion of hormones vitamins $\mathrm{B}$ and antibiotics, activities of enzymes and water retention and reducing soil $\mathrm{pH}$ and salinity (Simon et al., 1999 and Chen et al., 2004).

Previous studies showed that using organic manures enriched with different microorganisms as partial replacement of inorganic $\mathrm{N}$ was useful for promoting yield and quality of berries in various grapevine cvs (Abada, 2009; Madian, 2010; Refaai, 2011; Uwakiem, 2011; El-Wany, 2016; Aly-Samar, 2015; Motawea, 2015 and Tony, 2016).

The target of this study was evaluating the effect of replacing inorganic $\mathrm{N}$ fertilizers partially by different organic manures enriched with Spirulina platensis algae on yield and fruit quality of Superior grapevines.

\section{MATERIALS AND METHODS}

This study was carried out during the three consecutive seasons of 2014, 2015 and 2016 on ninety uniform in vigour 8-years old Superior grapevines grown in a private vineyard located at El-Hawarta Village, Minia district, Minia Governorate, where the soil texture is clay and well drained water since water table depth is not less than two meters. The chosen vines were planted at $2 \times 3$ meters apart. Cane pruning system was followed at the first week of Jan. leaving 84 eyes per vine (on the basis of six fruiting canes x 12 eyes plus six renewal spurs $\mathrm{x}$ two eyes) with the assistance of Gable shape supporting system. The vines were irrigated through flood irrigation system using Nile water.

The experimented vines (90 vines) received the usual horticultural practices which are commonly used in the vineyard, except those dealing with the present treatments (all sources of $\mathrm{N}$ ) and biofertilization.

This study included the following ten treatments from inorganic $\mathrm{N}$, organic manures and Spirulina platensis algae:

1. Application of the recommended $\mathrm{N}$ dose $(60 \mathrm{~g} \mathrm{~N} /$ vine/ year $)$ via $100 \%$ inorganic N (179.0 g ammonium nitrate / vine / year) alone. 
2. Application of the recommended $\mathrm{N}$ via $75 \%$ Inorganic $\mathrm{N}$ dose $(134.3 \mathrm{~g}$ ammonium nitrate / vine / year $)+25 \%$ plant compost $(2.0 \% \mathrm{~N})(0.75 \mathrm{~kg} /$ vine / year) + $10 \mathrm{ml}$ Spirulina platensis algea / vine / year.

3. Application of the recommended $\mathrm{N}$ dose via $75 \%+25 \%$ farmyard manure $(0.25 \% \mathrm{~N})(6 \mathrm{~kg} / \mathrm{vine} /$ year $)+10 \mathrm{ml}$ Spirulina platensis algae / vine / year.

4. Application of the recommended $\mathrm{N}$ dose via $75 \%$ inorganic $\mathrm{N}+25 \%$ poultry manure $(2.5 \% \mathrm{~N})(0.6 \mathrm{~kg} / \mathrm{vine} /$ year $)+10 \mathrm{ml}$ Spirulina platensis algae / vine / year.

5. Application of the recommended $\mathrm{N}$ dose via $50 \%$ inorganic $\mathrm{N}$ (89.5 g ammonium nitrate / vine/ year $)+50 \%$ plant compost $(1.5 \mathrm{~kg} /$ vine/ year $)+$ $20 \mathrm{ml}$ Spirulina platensis algae / vine / year.

6. Application of the recommended $\mathrm{N}$ dose via $50 \%$ inorganic $\mathrm{N}+50 \%$ farmyard manure $(12 \mathrm{~kg} /$ vine/ year $)+20 \mathrm{ml}$ Spirulina platensis algae / vine/ year.

7. Application of the recommended $\mathrm{N}$ dose via $50 \%$ inorganic $\mathrm{N}+50 \%$ poultry manure $(1.2 \mathrm{~kg} /$ vine/ year $)+20 \mathrm{ml}$ Spirulina platensis algae / vine/ year.

8. Application of the recommended $\mathrm{N}$ dose via $25 \%$ inorganic $\mathrm{N}$ (44.8 g ammonium nitrate / vine/ year) $+75 \%$ plant compost ( $2.25 \mathrm{~kg} /$ vine/ year $)+$ 40 Spirulina platensis algae / vine/ year.

9. Application of the recommended $\mathrm{N}$ dose via $25 \%$ inorganic $\mathrm{N}+75 \%$ farmyard manure ( $18 \mathrm{~kg} /$ vine/ year) $+40 \mathrm{ml}$ Spirulina platensis algae / vine/ year.

10. Application of the recommended $\mathrm{N}$ dose via $25 \%$ inorganic $\mathrm{N}+75 \%$ poultry manure $(1.8 \mathrm{~kg} /$ vine/ year $)+40 \mathrm{ml}$ Spirulina platensis algae / vine/ year.

Each treatment was replicated three times, three vines per each. Ammonium nitrate $(33.5 \% \mathrm{~N})$ as a source of inorganic $\mathrm{N}$ was divided into three unequal batches as $45 \%$ at growth start (1st week of March), 20\% before blooming (1st week of April) and 35\% just after berry setting (3rd week of April). Spirulina platensis algae was added once before growth start (1st week of March) in shallow holes $20 \mathrm{~cm}$ apart from the trunk and covered with moist soil. The three organic manures were added once just after winter pruning (3rd week of January) $55 \mathrm{~cm}$ from the vine trunk in drenches $(50 \times 50 \times 50 \mathrm{~cm}$ dimensions). Analyses of the three organic manures and Spirulina platensis algae are given in Tables $(1,2,3,4 \& 5)$. 
Table (1): Analysis of the experiment soil

\begin{tabular}{|l|c|}
\hline Constituents & Values \\
\hline \hline Particle size distribution: & \\
\hline Sand \% & 7.0 \\
\hline Silt \% & 21.5 \\
\hline Clay \% & 71.5 \\
\hline Texture & Clay \\
\hline $\mathrm{pH}(1: 2.5$ extract $)$ & 7.95 \\
\hline $\mathrm{EC}(1: 2.5$ extract $)\left(\mathrm{dsm}^{-1}\right) 1 \mathrm{~cm} / 25^{\circ} \mathrm{C}$. & 0.97 \\
\hline O.M. $\%$ & 2.01 \\
\hline CaCO $\%$ & 2.41 \\
\hline Total N \% & 0.11 \\
\hline Available P $($ Olsen, $\mathrm{ppm})$ & 3.11 \\
\hline Available K $($ ammonium acetate, $\mathrm{ppm})$ & 405.9 \\
\hline
\end{tabular}

Table (2): Analysis of plant compost

\begin{tabular}{|c|c|}
\hline Parameters & 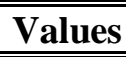 \\
\hline Cubic meter weight (kg.) & 600.0 \\
\hline Moisture \% & 29.0 \\
\hline Organic matter $\%$ & 30.7 \\
\hline Organic carbon $\%$ & 28.56 \\
\hline $\mathrm{pH}(1: 2.5$ extract $)$ & 7.25 \\
\hline $\mathrm{EC}\left(\mathrm{dsm}^{-1}\right)(1: 2.5$ extract $)$ & 10.25 \\
\hline $\mathrm{C} / \mathrm{N}$ ratio & 14.28 \\
\hline Total N \% & 2.0 \\
\hline Total P \% & 1.02 \\
\hline Total K \% & 1.21 \\
\hline Total Ca \% & 1.25 \\
\hline Total Mg \% & 1.30 \\
\hline Total Fe ( ppm) & 18.5 \\
\hline Total Mn ( ppm) & 37.55 \\
\hline Total Zn ( ppm) & 43.22 \\
\hline Total $\mathrm{Cu}(\mathrm{ppm})$ & 17.40 \\
\hline
\end{tabular}


Table (3): Analysis of farmyard manure

\begin{tabular}{|l|c|}
\hline Parameters & Values \\
\hline \hline O.M. \% & 8.9 \\
\hline Total N \% & 0.25 \\
\hline $\mathrm{P} \%$ (Olsen method) & 0.5 \\
\hline $\mathrm{K} \%($ ammonium acetate) & 1.6 \\
\hline $\mathrm{pH}(1: 2.5$ extract) & 3.3 \\
\hline $\mathrm{Zn}(\mathrm{ppm})$ & 36.0 \\
\hline $\mathrm{Fe}(\mathrm{ppm})$ & 15.5 \\
\hline
\end{tabular}

Table (4): Analysis of poultry manure

\begin{tabular}{|l|c|}
\hline Parameters & Values \\
\hline \hline O.M. $\%$ & 58.26 \\
\hline Organic carbon & 27.90 \\
\hline $\mathrm{pH}(1: 2.5$ extract $)$ & 6.25 \\
\hline E.C. $(1: 2.5$ extract $)\left(\mathrm{dsm}^{-1}\right)$ & 5.9 \\
\hline Total $\mathrm{N} \%$ & 2.5 \\
\hline Total $\mathrm{P} \%$ & 1.12 \\
\hline Total K \% & 1.21 \\
\hline Total Fe $(\mathrm{ppm})$ & 18.5 \\
\hline Total $\mathrm{Zn}(\mathrm{ppm})$ & 43.22 \\
\hline
\end{tabular}


Table (5): Chemical analysis of Spirulina platensis algae (according to Koru et al., 2008).

\begin{tabular}{|l|c|}
\hline Parameters & Values \\
\hline \hline General composition $($ per $\mathbf{1 0 0}$ g $)$ & \\
\hline \hline Moisture & $3.5 \mathrm{~g}$. \\
\hline Protein & $63.5 \mathrm{~g}$. \\
\hline Fat ( Lipids) & $9.5 \mathrm{~g}$. \\
\hline Fibre & $3.00 \mathrm{~g}$. \\
\hline Ash & $6.70 \mathrm{~g}$. \\
\hline N- free extract & $15 . \mathrm{g}$. \\
\hline \hline Colorants & \\
\hline \hline Phycocyanin & $15.6 \mathrm{~g}$. \\
\hline Carotenoids & $456.00 \mathrm{mg}$. \\
\hline Chlorophyll- a & $1.30 \mathrm{~g}$. \\
\hline \hline Vitamins & \\
\hline \hline Provitamin $\mathrm{A}$ & $213.00 \mathrm{mg}$. \\
\hline Thiamin $\left(\mathrm{V} . \mathrm{B}_{1}\right)$ & $1.92 \mathrm{mg}$. \\
\hline Riboflavin $\left(\mathrm{V} . \mathrm{B}_{2}\right.$ ) & $3.44 \mathrm{mg}$. \\
\hline Vitamin $\mathrm{B}_{6}$ & $0.49 \mathrm{mg}$. \\
\hline Vitamin $\mathrm{B}_{12}$ & $0.12 \mathrm{mg}$. \\
\hline Vitamin E & $10.40 \mathrm{mg}$. \\
\hline Niacin & $11.30 \mathrm{mg}$. \\
\hline Folic acid & $40 \mathrm{mg}$. \\
\hline Pantothenic acid & $0.94 \mathrm{mg}$. \\
\hline Inositol & $76.00 \mathrm{mg}$. \\
\hline \hline Minerals & \\
\hline \hline Phosphorus & $916.00 \mathrm{mg}$. \\
\hline Iron & $53.60 \mathrm{mg}$. \\
\hline Calcium & $168 \mathrm{mg}$. \\
\hline Potassium & $1.83 \mathrm{~g}$. \\
\hline Sodium & $1.09 \mathrm{~g}$. \\
\hline Magnesium & $250 \mathrm{mg}$. \\
\hline
\end{tabular}


Randomized complete block design (RCBD) was followed (Rangaswamy, 1995), where the experiment consisted of ten treatments, each treatment was replicated three times, three vines per each.

During each season, the following parameters were recorded:

1. Growth aspects namely main shoot length $(\mathrm{cm})$, leaf area and pruning wood weight/vine (Ahmed and Morsy, 1999), wood ripening coefficient (Bouard, 1966) and cane thickness $(\mathrm{cm})$..

2. Leaf chemical components namely chlorophylls a, b, total chlorophylls (mg/100 g F.W) (Von- Wettstein, 1979 and Fadle and Seri El-Deen, 1978), N, P and K (Wilde et al. 1985 and Balo et al, 1988).

3. Yield expressed in weight and number of clusters/vine as well as cluster weight and dimensions (length and shoulder).

4. Percentages of shot berries.

5. Physical and chemical characteristics of the berries esecially weight, longitudinal and equatorial, TSS, total acidity\%, reducing sugars $\%$ (A.O.A.C, 2000) and nitrite in the juice (ppm) (Riodnour-Lisa et al., 2000).

Statistical analysis was done and treatment means were compared using new L.S.D. at 5\% (according to Mead et al., 1993 and Rao, 2007).

\section{RESULTS AND DISCUSSION}

\section{1- Vegetative growth characteristics:}

It is clear from the obtained data in Table (6) that the five vegetative growth characteristics namely main shoot length, leaf area, wood ripening coefficient, wood pruning weight and cane thickness were significantly affected within the ten nitrogen management treatments. Under organic and biofertilization conditions, reducing the percentages of inorganic $\mathrm{N}$ from 75 to $50 \%$ of the recommended $\mathrm{N}$ dose caused a gradual stimulation on these growth characteristics. Generally, using the recommended $\mathrm{N}$ dose via inorganic $\mathrm{N}$ at 50 to $75 \%$ besides organic and biofertilization with any of the three organic manures at 25 to $50 \%$ and Spirulina platensis algae at 10 to 20 $\mathrm{ml} /$ vine / year significantly stimulated all growth characteristics rather than using $\mathrm{N}$ as inorganic $\mathrm{N}$ at $100 \%$ or when inorganic $\mathrm{N}$ was added as $25 \%$ with organic and biofertilization. The promotion on such growth aspects was significantly associated with reducing the percentages of inorganic $\mathrm{N}$ from 75 to $50 \%$ and at the same time increasing levels of both organic manures from 25 to $50 \%$ and Spirulina platensis algae from 10 to $20 \mathrm{ml} /$ vine. Using the recommended $\mathrm{N}$ dose via $25 \%$ inorganic $\mathrm{N}$ under organic and 
biofertilization with any of the three organic manures and Spirulina platensis algae at $40 \mathrm{ml} /$ vine significantly reduced these growth characteristics comparing with using inorganic $\mathrm{N}$ at 50 to $75 \%$ plus using organic and biofertilization or when $\mathrm{N}$ was completely as inorganic $\mathrm{N}$. In descending order, the best organic manures in this respect were poultry manure, plant compost and farmyard manure.

The maximum values of main shoot length $(116,117.1$ and $118.8 \mathrm{~cm})$, leaf area $\left(117.9,119.7\right.$ and $\left.121.4 \mathrm{~cm}^{2}\right)$, wood ripening coefficient $(0.93,0.91$ and 0.94$)$, pruning wood weight $(2.95,2.88 \& 3.0 \mathrm{~kg} / \mathrm{vine})$ and cane thickness $(1.18,1.24 \& 1.22 \mathrm{~cm})$ were recorded on the vines fertilized with $\mathrm{N}$ as $50 \%$ inorganic $\mathrm{N}+50 \%$ poultry manure $+20 \mathrm{ml}$ Spirulina platensis algae / vine during the three seasons, respectively. Fertilizing Superior grapevines with $\mathrm{N}$ as $25 \%$ inorganic $\mathrm{N}$ plus application of farmyard manure at $75 \%$ and Spirulina platensis algae at $40 \mathrm{ml} /$ vine/ year gave the minimum values of main shoot length $(81.0,82.1 \& 84.0 \mathrm{~cm})$, leaf area $(99.3,101.0 \& 101.7$ $\left.\mathrm{cm}^{2}\right)$, pruning wood weight $(1.99,1.91 \& 2.03)$, wood ripening coefficient $(0.69,0.67 \& 0.70 \mathrm{~kg}$. $)$ and cane thickness $(0.78,0.83 \& 0.82 \mathrm{~cm})$ in the three seasons, respectively. These results were true during three seasons.

\section{2- Total chlorophylls:}

It is clear from Table (6) that varying percentages of inorganic $\mathrm{N}$ and organic manures and levels of Spirulina platensis algae caused a significant effect on total chlorophylls. Supplying the vines with N as 25 to $75 \%$ inorganic $\mathrm{N}$ plus any one of the three organic manures (plant compost, farmyard manure and poultry manure) each at $25-75 \%$ enriched with Spirulina platensis algae at 10 to $40 \mathrm{ml} /$ vine/ year significantly enhanced total chlorophylls content comparing with using $\mathrm{N}$ as $100 \%$ inorganic $\mathrm{N}$. The promotion on the leaf pigments was significantly in proportional to the reduction in the percentages of inorganic $\mathrm{N}$ from 100 to $25 \%$ and at the same time increasing of organic manures percentages from 0.0 to $75 \%$ and the levels of Spirulina platensis algae from 0 to $40 \mathrm{ml}$ vine/ year. The best organic manures in enhancing these plant pigments from statistical point of view were poultry manure, plant compost and farmyard manure, in descending order.

The maximum values of total chlorophylls $(24.0,24.9 \& 25.8 \mathrm{mg} / 100$ g. FW), were recorded on the vines supplied with $\mathrm{N}$ as $25 \%$ inorganic $+75 \%$ poultry manure $+40 \mathrm{ml}$ Spirulina platensis algae / vine/ year. The vines that received $\mathrm{N}$ as $100 \%$ inorganic gave the lowest values (14.1, 15.0\& 15.9 
mg/100g FW) during 2014 \& 2015 and 2016 seasons, respectively. These results were significant during the three seasons.

\section{3- The percentages of $N, P$ and $K$ in the leaves.}

It is evident from Tables $(6 \& 7)$ that the tested $N$ management had significant effect on the percentages of $\mathrm{N}, \mathrm{P}$ and $\mathrm{K}$ in the leaves. Fertilizing the vines with $\mathrm{N}$ through 25 to $75 \%$ inorganic $\mathrm{N}+$ any one of the three organic manures (poultry manure, plant compost and farmyard manure) each at 25 to $75 \%$ + Spirulina platensis algae at 10 to $40 \mathrm{ml} /$ vine/ year was significantly accompanied with enhancing these nutrients over the application of $\mathrm{N}$ as $100 \%$ inorganic $\mathrm{N}$. There was a significant and gradual increase in these nutrients ( $\mathrm{N}, \mathrm{P}$ and $\mathrm{K}$ ) in the leaves with reducing the inorganic $\mathrm{N}$ percentages from 100 to $25 \%$ and increasing the of organic manures percentages from 0.0 to $75 \%$ and levels of Spirulina platensis algae for each vine from 0.0 to $40 \mathrm{ml}$. Supplying the vines with poultry manure, plant compost and farmyard manure each at 25 to $75 \%$ of $\mathrm{N}$, significantly for enhanced these nutrients in the leaves. The highest percentages of $\mathrm{N}(2.21$, $2.17 \& 2.13 \%), \mathrm{P}(0.28,0.27 \& 0.29 \%)$ and $\mathrm{K}(1.71,1.65 \& 1.78 \%)$ were recorded for the vines supplied with $\mathrm{N}$ as $25 \%$ inorganic $+75 \%$ poultry manure $+40 \mathrm{ml}$ Spirulina platensis algae / vine/ year. The vines that were fertilized with $\mathrm{N}$ completely via inorganic form gave the lowest percentages of $\mathrm{N}(1.60,1.56 \& 1.52 \%), \mathrm{P}(0.11,0.09 \& 0.10 \%)$ and $\mathrm{K}(1.11,1.14 \&$ $1.18 \%$ ) during the three seasons, respectively. Similar results were announced during the three seasons.

\section{4-Yield and cluster characteristics:}

Data in Table (7) revealed that all inorganic $\mathrm{N}$, organic manures and Spirulina platensis algae treatments had significant effects on the yield and number of clusters per vine as well as cluster weight and dimensions (length $\&$ shoulder). Supplying the vines with $\mathrm{N}$ as 50 to $75 \%$ inorganic N +25 to $50 \%$ organic manures +10 to $20 \mathrm{ml}$ Spirulina platensis algae / vine/ year significantly improved these parameters comparing to using $\mathrm{N}$ completely via inorganic $\mathrm{N}$ or when inorganic $\mathrm{N}$ was applied at $25 \%+75 \%$ organic manures (poultry manure, plant compost or farmyard manure) enriched with Spirulina platensis algae at $40 \mathrm{ml} /$ vine/ year. Poultry manures was the best organic manures in improving berry setting \%, yield and cluster characteristics, followed by, plant compost and farmyard manure, in descending order. Using $\mathrm{N}$ as $100 \%$ inorganic $\mathrm{N}$ was favourable than using $\mathrm{N}$ as $25 \%$ inorganic with 
organic and biofertilization in this respect. A significant decline in yield and cluster characteristics was observed when the percentage of inorganic $\mathrm{N}$ was lowered to $25 \%$ even with the application of organic manures at $75 \%$ and Spirulina platensis algae at $40 \mathrm{ml} /$ vine/ year. There was a gradual and significant promotion in these parameters with reducing the percentages of inorganic $\mathrm{N}$ from 100 to $50 \%$ and increasing the percentages of organic manures from 0.0 to $50 \%$ and the levels of Spirulina platensis algae from 0.0 to $20 \mathrm{ml} /$ vine / year.

The maximum yield / vine $(9.7,12.3 \& 12.8 \mathrm{~kg})$ and cluster weight (422.0, 425.0 and $426.7 \mathrm{~g}$ ) were recorded for the vines that received $\mathrm{N}$ as $50 \%$ inorganic $\mathrm{N}+20 \%$ poultry manure $+20 \mathrm{ml}$ Spirulina platensis algae vine / year during the three seasons, respectively. The lowest values of yield/ vine $(7.3,6.7 \& 6.7 \mathrm{~kg})$ and cluster weight $(330.0,332.5 \& 334.0 \mathrm{~g})$ were gained by vines fertilized with $\mathrm{N}$ as $25 \%$ inorganic $+75 \%$ farmyard manure $+40 \mathrm{ml}$ Spirulina platensis algae / vine/ year during the three seasons, respectively. The yield of the vines that were fertilized with $\mathrm{N}$ as $100 \%$ inorganic $\mathrm{N}$ reached $(7.9,8.6 \& 8.3 \mathrm{~kg}$.) during the three seasons, respectively. The percentage of increment on the yield due to using the previous promised treatment $(50 \%$ inorganic $+50 \%$ poultry manure $+20 \mathrm{ml}$ Spirulina platensis algae / vine) over the check treatment (application of $\mathrm{N}$ as $100 \%$ inorganic N) reached $22.8,43.0 \& 54.2 \%$ during the three seasons, respectively. These results were confirmed during the three seasons.

\section{5- Shot berries and berry quality:}

It is obvious from the obtained data in Tables ( $8 \& 9)$ that supplying the vines with $\mathrm{N}$ as 25 to $75 \%$ inorganic +25 to $75 \%$ organic manures +10 to $40 \mathrm{ml}$ Spirulina platensis algae / vine/ year significantly reduced the percentage of shot berries and improved fruit quality in terms of increasing weight, longitudinal and equatorial berry TSS \%, while reduced sugars $\%$ and total anthcoyanins content and total acidity \% compared with using $\mathrm{N}$ as $100 \%$ inorganic $\mathrm{N}$. The improving in fruit quality and the reduction in shot berries $\%$ were significantly related to reducing the percentages of inorganic $\mathrm{N}$ from 100 to $25 \%$ and increasing the percentages of organic manures from 0.0 to $75 \%$ and the levels of Spirulina platensis algae from 0.0 to $40 \mathrm{ml} / \mathrm{vine} /$ year. The best organic manure in this respect was poultry manure, followed by plant compost and farmyard manure, in descending order. Inorganic fertilization alone gave unfavourable effects on shot berries and quality of the berries. The best results with regard to shot berries reduction and improving 
fruit quality were obtained due to fertilizing the vines with $\mathrm{N}$ as $25 \%$ inorganic $\mathrm{N}+75 \%$ poultry manure $+40 \mathrm{ml}$ Spirulina platensis algae / vine/ year. Percentage of shot berries in the clusters reached the minimum values $(2.0,2.1$ and $1.9 \%)$ when the vines were fertilizing with $\mathrm{N}$ as $25 \%$ inorganic $\mathrm{N}+75 \%$ poultry manure $+40 \mathrm{ml}$ Spirulina platensis algae / vine/ year during the three seasons, respectively. The maximum shot berries percentages (5.9, $6.4 \& 7.0 \%$ ) were recorded for vines supplied with $\mathrm{N}$ as $100 \%$ inorganic $\mathrm{N}$ during the three seasons, respectively. These results were true during the three seasons.

\section{6- Nitrite content in the juice:}

It is clear from Table (9) that supplying the vines with $\mathrm{N}$ as 25 to $75 \%$ inorganic +25 to $75 \%$ organic manures +10 to $40 \mathrm{ml}$ Spirulina platensis algae / vine/ year significantly reduced the juice content of nitrite comparing with using $\mathrm{N}$ as $100 \%$ inorganic $\mathrm{N}$. The reduction in nitrite juice content was significantly related to reducing the percentages of inorganic $\mathrm{N}$ from 100 to $25 \%$ and increasing the percentages of organic manures from 0.0 to $75 \%$ and the levels of Spirulina platensis algae from 0.0 to $40 \mathrm{ml} /$ vine/ year. Poultry manure the best organic manures in this respect followed by plant compost and farmyard manure, in descending order. Inorganic fertilization alone gave unfavorable effects on the juice content of nitrite. The best results with regard to the reduction of nitrite in the juice were obtained due to supplying the vines with $\mathrm{N}$ as $25 \%$ inorganic $\mathrm{N}+75 \%$ poultry manure $+40 \mathrm{ml}$ Spirulina platensis algae / vine/ year. Nitrite juice content reached the minimum values $(0.61,0.55$ and $0.44 \mathrm{ppm})$ when the vines were fertilized with $\mathrm{N}$ as $25 \%$ inorganic $\mathrm{N}+75 \%$ poultry manure $+40 \mathrm{ml}$ Spirulina platensis algae / vine/ year during the three seasons, respectively. The highest contents of nitrite in the juice $(1.95,1.90 \& 1.80 \mathrm{ppm})$ were recorded for vines received $\mathrm{N}$ completely via in organic $\mathrm{N}$ during 2014, 2015 and 2016 seasons, respectively. These results were true during the three seasons.

\section{DISCUSSION}

The previous promoting effect of organic fertilization combined with biofertilization using blue algae (Spirulina platensis) as partial replacement of mineral $\mathrm{N}$ fertilizers on vine nutritional status, yield and fruit quality of Superior grapevines can be attributed to the positive role played by these aforementioned microorganisms in providing essential nutrients required for 
optimization of plant growth (Koru, 2009 and Henrikson, 2010), and their essential roles in soil fertility as they improve the biological, physical and chemical properties of the soil (Kannaiyan, 2002). On the other hand, Spirulina platensis algae is especially rich in nutrients and growth promoting constituents including amino acids, antioxidants and vitamins (Koru et al., 2008; Koru, 2009 and Henrikosn, 2010).

In addition, organic fertilization plays an important role in improving the soil conditions and decreasing mineral $\mathrm{N}$ fertilizer toxic effects. Moreover, organic fertilization plant compost FYM and poultry manure in the current study is known to reduce soil-borne pathogens, problems of salinity, soil $\mathrm{pH}$, leaching process and soil erosion and enhancing the production of growth promoting substances, i.e. IAA, $\mathrm{GA}_{3}$ and cytokinins, which in turn improve root development. Together with biofertilization, organic manures increase nutrients availability and uptake, soil organic matter and microbial activity, soil aggregation and aeration, permeability of soil and water holding capacity. Moreover, these organic and biofertilizers are known to enhance nutrient transport, photosynthesis process, $\mathrm{N}$ fixation, water uptake, vitamins B, solubility of most nutrients, soil workability, resistance to drought, buffering property of the soil, formation of heavy metal complexes, breaking of hazard chemicals, formation of hummus, tolerance to drought and temperature extremes, oxidation of sulphur complexes and converting insoluble sulphur to soluble one (Simon et al, 1999 and Chen et al, 2004).

These beneficial effects of organic manures and biofertilization surely reflected on enhancing growth characteristics, soil fertility, plant pigments and vine nutritional status consequently caused enhancement on fruiting status. Moreover, the increase in berry setting, number of clusters per vine and cluster weight resulted from these biostimulants surely reflected in improving the yield/vine. The great promotion on the biosynthesis and translocation of carbohydrates due to these amendments could result in advancing maturity and improving quality of the berries.

In addition, the great control on the uptake of $\mathrm{N}$ by the vines due to using organic and biofertilization surely reflected on reducing the accumulation of both nitrites and nitrates in the berries. Thus, the application of these results would lower environmental pollution.

The results of this study are in agreement with those of the previous studies that emphasized the beneficial effects of organic manures and 
biofertilization in promoting yield and fruit quality in various grapevine cvs. (Refaai, 2011; Aly-Samar, 2015; El-Wany, 2015 and Motawea, 2016).

In addition, the findings of the recent studies provide further support for the results of this study. Both fruiting and berry quality aspects were improved in response to biofertilization and/or organic fertilization in comparison to inorganic fertilization alone as previously reported by Madian (2010) and Refaai (2011).

Conclusively, for enhancing growth and yield of Superior grapevines, it is suggested to supply the vines with $\mathrm{N}(60 \mathrm{~g} / \mathrm{vine} / \mathrm{year})$ through $50 \%$ inorganic $\mathrm{N}+50 \%$ poultry manure enriched with Spirulina platensis algae at $20 \mathrm{ml} /$ vine/year. Fertilizing the vines with $\mathrm{N}$ as $25 \%$ inorganic $\mathrm{N}+75 \%$ poultry manure enriched with $40 \mathrm{ml}$ Spirulina platensis algae gave the best results with regard to berries quality.

\section{REFERENCES}

Abada, M.A.M. (2009): Reducing the amount of inorganic $\mathrm{N}$ fertilizers in Superior vineyard by using organic and biofertilizers and humic acid. Egypt, J. Agric. Res. 87(1): 17-344.

Ahmed, F. F. and Morsy, M. H. (1999): A new method for measuring leaf area in different fruit crops. Minia of Agric. Res. \& Develop. (19): 97-105.

Aly-Samar, S. H. (2015): Influence of reducing mineral nitrogen fertilizer partially by using plant compost enriched with Spirulina platensis algae fruiting of Flame Seedless grapevines. M. Sc, Thesis. Fac. of Agric. Minia Univ.

A. O. A. C. (2000): Official Methods of Analysis (A.O.A.C), $17^{\text {th }}$ Ed. Benjamin Franklin Station, Washington D.C. U.S.A. pp.490-510.

Balo, E.; Prilezky, G.; Happ, I. Kaholomi, M. and Vega, L. (1988): Soil improvement and the use of leaf analysis for forecasting nutrient requirements of grapes. Potash Review subject $2^{\text {nd }}$ suite No.6.

Bouard, J. (1966): Recharches, physiologiques sur la vigen at en particulier sur laoudment des serments. Thesis Sci. Nat. Bardeux France, p.34.

Chen, Y.; De Nobili, M.; Aviad, T. (2004): Stimulatory effects of humic substances on plant growth. In: F. MAGDOFF; R. R. WEIL (Eds.): Soil organic matter in sustainable agriculture, 103-129. CRC Press, New York, USA. 
El-Wany, A.R.M. (2015): Response of Thompson Seedless grapevines to application of EM and fulvic acid as a partial replacement of inorganic $\mathrm{N}$ fertilizer. M. Sc. Thesis Fac. of Agric. Minia Univ. Egypt.

Fadle, M.S. and Seri El- Deen, S.A. (1978): Effect of N Benzyl adenine on photosynthesis, pigments and total sugars on olive seedling grown under saline conditions, Res. Bull. No. 873, Fac. Agric., Ain Shams Univ., Egypt

Henrikson, R. (2010): Spirulina World food, how this micro alga can transform your health and our planet, published by Ronore Enterprises, Inc. Po. Box gog. Hana, Maui, Hawaii $967 i 8$ USA, ISBN 1453766987, pp. 195.

Kannaiyan, S. (2002): Biotechnology of Biofertilizers. Alpha Science International Ltd Panpabourne England, P. 1-275.

Koru, E. (2009): Spirulina micro algae production and breeding in commercial. Turkey Journal of Agriculture, May June 2008, Issue: 11: 133- 134.

Koru, E.; Cirik, S. and Turan, G. (2008): The use of Spirulina for feed production in Turkey University- industry co- operation project (USIGEM) project investigator and consultant Eids Koru, pp. 100, Bornova- Izmir/Turkey.

Madian, A. M. (2010): Adjusting the best source and proportion of mineral, organic and bio nitrogen fertilizers on Superior grapevines (Vitis vinifera L.). Ph. D. Thesis Fac. of Agric., Minia Univ., Egypt.

Mead, R.; Currnow, R. N.; and Harted, A. M. (1993). Statistical Methods in Agricultural and Experimental Biology. Second Ed. Chapman \& Hall London. pp. $54-60$.

Motawea, S. M. H. (2016): Effect of using some organic manures enriched with $\mathrm{EM}_{1}$ as a partial replacement for mineral $\mathrm{N}$ fertilizers in Superior vineyards. M. Sc. Thesis, Fac. of Agric. Minia Univ. Egypt.

Rangaswamy R (1995): Randomized Complete Block Design. In: A Text Book of Agricultural Statistics. New Age International Publishers, pp 281-309.

Rao, G.N. (2007): Statistics for Agricultural Sciences. BS Publications.

Refaai, M. M. (2011): Productive capacity of Thompson Seedless grapevines in relation to some inorganic, organic and biofertilization as well as citric acid treatments. Ph. D. Thesis Fac. of Agric. Minia Univ. Egypt. 
Riodnour- Lisa, A.; Sim- Julia, E.; Michael, A.H.; David, A. W.; Sean, M.M.; Gorry, R.P. and Douglas, R.S. (2000): A Spectrophotometric method for the direct and quantitation of nitric oxide, nitrite and nitrate in cell culture media analysis Biochemisty, 281: 223-229.

Simon, S; Corroyer, N.; Gettig, F. X.; Girard, T.; Combe, F.; Fauriel, J. and Bussi, C. (1999): Organic farming: optimization of techniques. Arboriculture Fruitier, 533: 27- 32.

Tony, M.S.S. (2016): Partial replacement of inorganic $N$ fertilizer in Superior vineyard by using compost enriched with some microorganism. M.Sc. Thesis Fac. of Agric. Minia Univ., Egypt.

Uwakiem, M. Kh. (2011): Effect of some organic, bio and slow release N fertilizers as well as some antioxidants on vegetative growth, yield and berries quality of Thompson Seedless grapevines $\mathrm{Ph}$. D, Thesis. Fac. of Agric. Minia Univ. Egypt.

Von- Wettstein, D.V. (1957): Chlorophyll- Lthale under submikrosphpische formiuechrel der plastiden celi, Drp. Trop./ Res. Amer. Soc. Hort. Sci. 20: 427-433.

Wilde, S. A.; Corey, R. B.; Lyer, I. G. and Voigt, G. K. (1985): Soil and Plant Analysis for Tree Culture. $3^{\text {rd }}$ Oxford \& IBH publishing Co., New Delhi, pp. 1 - 218 .
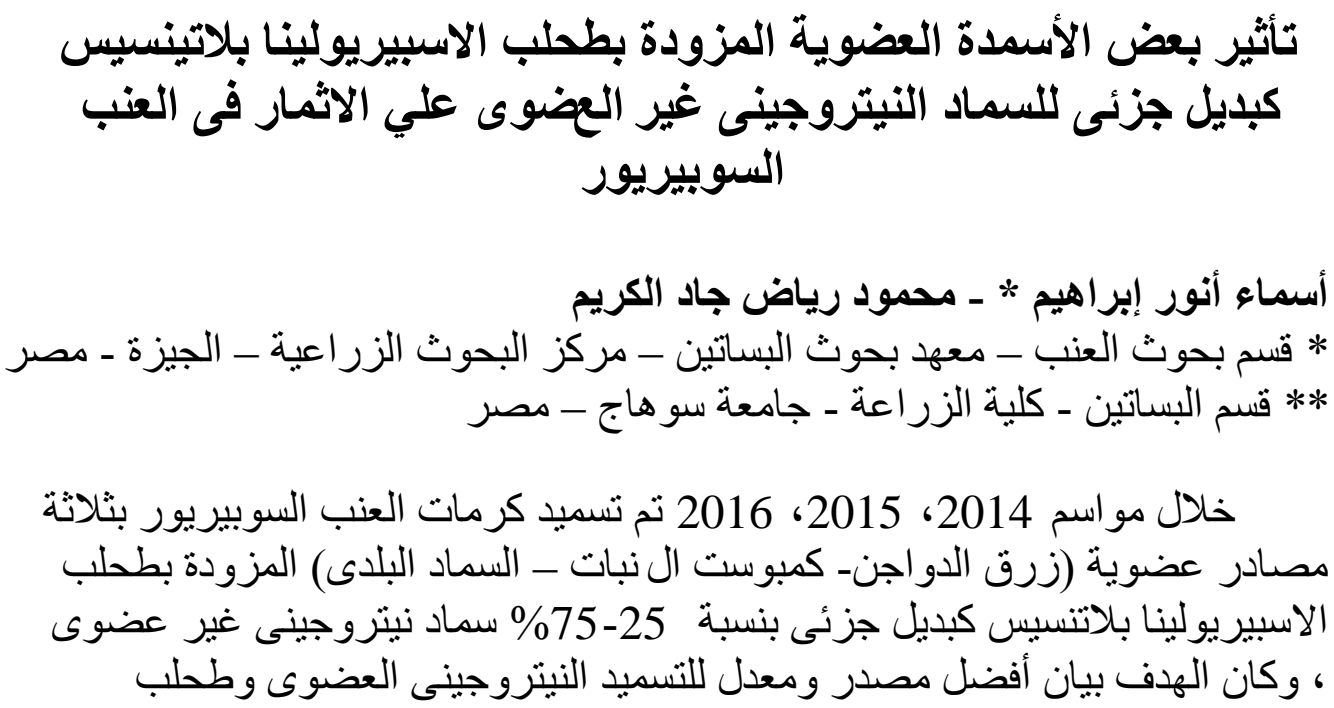
الاسبيريولينا بلاتنسيس المستخدم مع السماد النيتروجينى غير العضوى لانتاج محصول عالي وخصائص جودة عالية للحبات.

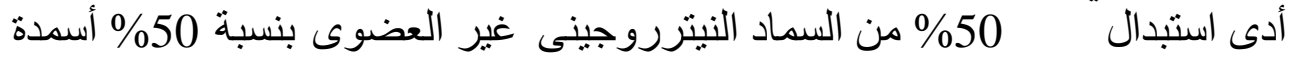

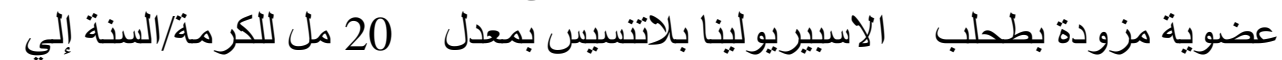

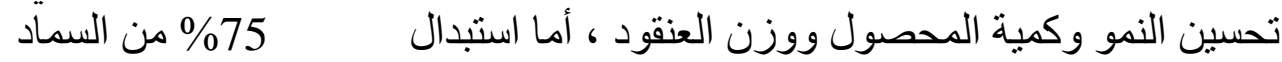
النيتروجينى غير العضوى بنسبة 75\% أسمدة عضوية مزودة بطحالب الاسبيريولينا

بلاتنسيس بمعدل 40 مل للكرمة/ السنة فقد كان فعالا في تحسين الحالة الغذائية

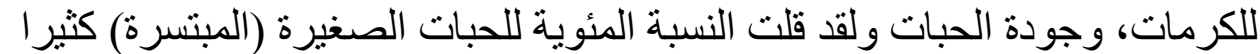

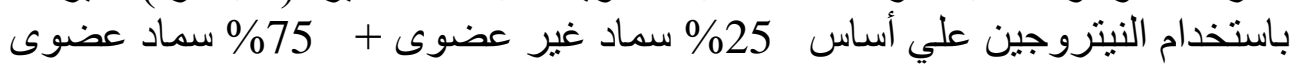

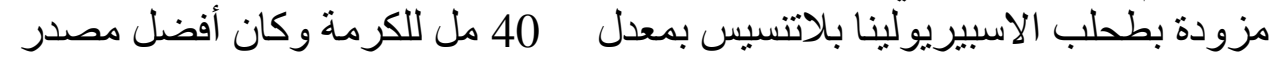
للسماد العضوى فيى هذا الصدد هو سماد زرق الدو اجن يليه كمبوست النبات ثم السماد البلدى مرتبة ترنيبا تناز ليا.

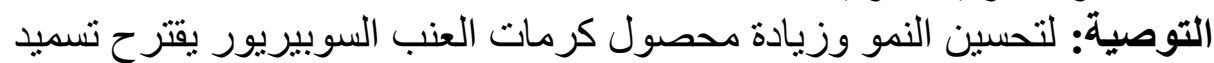
الكرمات بالنيتروجين (بمعدل 60 جر ام/السنة) خلال

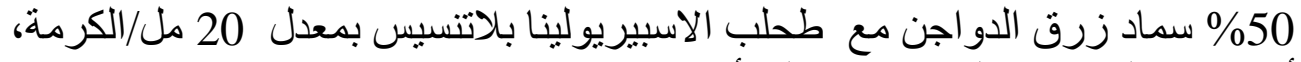

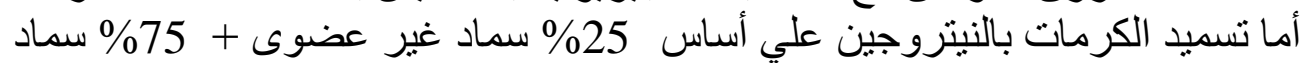

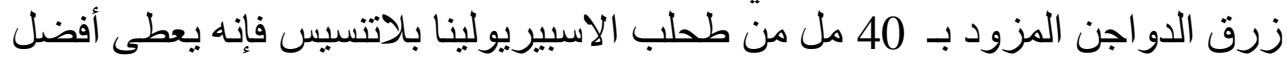
النتائج بخصوص الأ جون الخزد الحبات. 
